\title{
DNA-based biosensors with polyvinyl alcohol external membrane as a tool for the evaluation of antioxidant activity of white wines
}

\author{
Veronika Svitková, Lucia Steffelová, \\ Jana Blaškovičová, Ján Labuda \\ Slovak University of Technology in Bratislava, Faculty of Chemical and Food Technology, \\ Institute of Analytical Chemistry, Radlinského 9, 81237 Bratislava, Slovakia \\ veronika.svitkova@stuba.sk
}

\begin{abstract}
Electrochemical DNA-based biosensors with external protective membranes were prepared for the evaluation of antioxidant properties of white wines against pro-oxidant hydroxyl radicals. A glassy carbon working electrode (GCE) was modified using a layer-by-layer deposition technique with low molecular weight double stranded DNA and an outer sphere polymer film membrane of Nafion, chitosan or polyvinylalcohol. The composition of a working procedure with membrane-covered DNA biosensors were optimized with respect to their voltammetric response in solution of the DNA redox indicator $\left[\mathrm{Fe}(\mathrm{CN})_{6}\right]^{3-/ 4-}$ after the incubation in white wines. Polyvinylalcohol (PVA) film was proved to be the suitable membrane. The PVA/DNA/GCE biosensor was used for the detection of a deep degradation of the surface-attached DNA at the incubation in the cleavage agent and for the evaluation of antioxidant properties of white wines at the incubation in mixtures of cleavage agent and wine. The investigation of the biosensors with protective membranes represents a significant contribution to utilization of the electrochemical DNA based biosensors for practical purposes.
\end{abstract}

Keywords: electrochemical DNA biosensor, external protective membrane, DNA damage, antioxidant activity, white wine

\section{Introduction}

The quality and properties of wine are affected by large variety of different parameters like geographical origin, agricultural practices and chemical composition (Kirsanov et al., 2012). Wine is a mixture of numerous biologically active compounds and its nutritional importance is attributed to their antioxidant properties (Campanella et al., 2002). The "antioxidant power" of a food is an expression of its capability to defend the human organism from the action of free radicals and to prevent degenerative disorders deriving from persistent oxidative stress (Di Majo et al., 2008). Analysis of samples with complex matrix such as wine samples by usual analytical methods is often complicated, expensive and time consuming. Consequently researches have been directed to the development of methods and device as the biosensors that can characterize antioxidants in a fast, inexpensive and sensitive way. The use of cyclic voltammetry (CV) to determine the content and characterisation of easily oxidizable compounds in wines was suggested (Mannino et al., 1998; Kilmartin et al., 2001). Biosensors represent a broad area of technology useful for environmental, food and clinical analyses including evaluation of the antioxidant status (Ferancová et al., 2004; Heilerová et al., 2003; Mello and Kubota, 2007; Ziyatdinova et al., 2008).
DNA damage is a process resulting from the interaction of this biomacromolecule with physical or chemical agents occurring in the environment, causing an alteration in its chemical structure (Fojta, 2005). Degradation of DNA can be caused by generating free radicals such as reactive oxygen species (ROS) that oxidize the DNA bases and deoxyribose and cause release of the bases and strand breaks. Detection of this process belongs to one of the specific fields of analysis with DNA-based biosensors (Labuda, 2011). Voltammetric responses of DNA bases, intercalators and the $\left[\mathrm{Fe}(\mathrm{CN})_{6}\right]^{3-/ 4-}$ indicator present in solution are used as simple modes to detect the DNA damage and changes in the DNA structure through the quantification of the surface attached DNA. (Labuda and Vyskocil, 2011). Many natural and synthetic antioxidants exhibit an effective protection against the oxidative DNA damage and methods utilising the DNA cleavage inhibition are widely applied for their evaluation (Labuda et al., 2003).

External protective membranes have been reported to prevent the biosensor surface against an unwanted fouling and interferences of the biosensor surface. Typically, they are formed by polymers such as cellulose acetate, chitosan, and phospholipids, which are generally biodegradable, nontoxic, and effective barriers for small and large molecules 
(Leceta et al., 2013; Zajoncova and Pospiskova, 2009; Ambrozy et al., 2013). Chitosan is the most abundant cationic polymer widely used for biomedical and pharmaceutical applications. Chitosan has the ability to immobilize the enzymes (Yang et al., 2013; Mulyasuryani et al., 2010) and to entrap the DNA molecules (Galandova and Labuda, 2009). Nafion is a polymer with cation exchange properties. This negatively charged polymer is used to reduce the diffusion of small neutral and negatively charged interfering species (Poyrda et al., 1998). Polyvinylalcohol (PVA) is neutral polymer with good mechanical properties and excellent chemical resistance. It's biodegradable, easy to prepare and film forming (Kim et al., 2008; Srinivasa et al., 2003; Tripathi et al., 2010).

Recently, DNA biosensors with external protective membranes have been developed in our laboratory and successfully used to evaluate the antioxidant properties of several beverages, such as fruit juices (Ziyatdinova and Labuda, 2012), coffee, tea and beer (Hlavata et al., 2014). The aim of the present paper is evaluation of the antioxidant activity of various white wines, using voltammetric analytical response of the DNA-based biosensor with external membranes of Nafion (NAF), chitosan (CHIT) and polyvinylalkohol (PVA).

\section{Experimental}

\section{Reagents}

Low molecular weight salmon sperm dsDNA was obtained from Sigma-Aldrich, Germany. Its stock solution $\left(0.1 \mathrm{mg} \cdot \mathrm{ml}^{-1}\right)$ was prepared in a $0.1 \mathrm{M}$ phosphate buffer solution of $\mathrm{pH} 7.4$ and stored at $4{ }^{\circ} \mathrm{C}$. Polyvinylalcohol was obtained from Sigma-Aldrich, Germany and dissolved it nanopure water at $98{ }^{\circ} \mathrm{C}$ to the concentration of $0.1 \mathrm{mg} \cdot \mathrm{ml}^{-1}$. Chitosan from shrimp shells of low viscosity was obtained from Fluka, Germany. Its $0.5 \%(\mathrm{w} / \mathrm{w})$ solution of $\mathrm{pH}$ 5.0 was prepared in $1 \%(\mathrm{v} / \mathrm{v})$ acetic acid (Lachema, Czech Republic). Nafion (5\% (w/w)) was obtained from Sigma-Aldrich, Germany and its $1 \%(\mathrm{v} / \mathrm{v})$ solution was prepared by dilution in a $1: 1(\mathrm{v} / \mathrm{v})$ ethanol : water mixture. A phosphate buffer solution (PB) $(0.1 \mathrm{M}$ containing $10 \mathrm{mM} \mathrm{KCl}$, resulting $\mathrm{pH}$ 7.4) was used as the main component of supporting electrolyte. The cleavage mixture containing $9 \mathrm{mM}$ $\mathrm{H}_{2} \mathrm{O}_{2}, 0.1 \mathrm{mM} \mathrm{FeSO}_{4}$ and $0.4 \mathrm{mM}$ EDTA in PB was used for the hydroxyl radicals generation according to the Fenton reaction. Chemicals for $\mathrm{PB}$ and cleavage mixture preparation (Mikrochem, Slovakia) were of analytical reagent grade purity. Nanopure water $(18 \mathrm{M} \Omega \mathrm{cm})$ was used in all experiments. Commercially available samples of white wines Traminer, Green Veltliner and Riesling were pur- chased from Víno Levice, Bratislava, Müller Thurgau and Pinot Blanc from Château Topolčianky and Chardonnay from Víno Matyšák, Bratislava. All wines were produced in 2013.

\section{Apparatus}

Voltammetric measurements were performed using the potentiostat Autolab PGSTAT-100 and the software NOVA 1.10.13 (Metrohm Autolab, Netherlands). All measurements were carried out in three-electrode system using a glassy carbon working electrode (GCE), a silver|silver chloride reference electrode $(\mathrm{Ag} / \mathrm{AgCl} / \mathrm{sat} \mathrm{KCl})$ and a platinum counter electrode in a $10 \mathrm{ml}$ glass voltammetric cell. GCE was obtained from Metrohm, Netherlands and $\mathrm{Ag} / \mathrm{AgCl} /$ sat $\mathrm{KCl}$ and platinum electrodes were purchased from L-CHEM, Czech Republic.

\section{Preparation of the biosensors}

The surface of the working electrode was mechanically cleaned by using of "alumina slurry" $0.3 \mu \mathrm{m}$ (3 $\mu$ l) (Metrohm, Netherlands) applied to mohair papers. The GCE surface was pretreated by applying a potential of $1.6 \mathrm{~V}$ for $120 \mathrm{~s}$ in $10 \mathrm{ml}$ of the PB solution under stirring. This procedure was necessary to oxidize contaminants present on the surface and to activate the electrode surface for the dsDNA immobilization (Vyskocil et al., 2010). Then, a voltammetric control scan $\left(\mathrm{CV}\right.$ in $1 \mathrm{mM}\left[\mathrm{Fe}(\mathrm{CN})_{6}\right]^{3-/ 4-}$ in $\mathrm{PB}$ ) was performed to monitor a quality of the bare working electrode. Chemical modification of the electrode was carried out by covering the surface of the GCE by a layer of dsDNA deposited on the electrode surface from $0.1 \mathrm{mg} \cdot \mathrm{ml}^{-1}$ stock solution under the conditions of the adsorption potential of $+0.5 \mathrm{~V}$ vs. Ag/AgCl for $300 \mathrm{~s}$ in $\mathrm{PB}$ under stirring. Then, $2 \mu \mathrm{l}$ of NAF, CHIT or PVA stock solution were deposited and let to evaporate to dryness. The final biosensors were stable for several days, while keeping them in a dry atmosphere at a regular room temperature. All working electrodes were immersed in $\mathrm{PB}$ for 2 min under stirring to achieve equilibrium.

\section{Procedures}

For the cyclic voltammetry (CV) measurements, the electrodes (biosensors) was immersed into $1 \mathrm{mM}$ $\left[\mathrm{Fe}(\mathrm{CN})_{6}\right]^{3-/ 4-}$ in PB for 2 min under stirring, then $\mathrm{CV}$ records were obtained within a potential range from -0.4 to $0.8 \mathrm{~V}$ at a scan rate of $100 \mathrm{mV} \cdot \mathrm{s}^{-1}$ and a potential step of $2 \mathrm{mV}$. For the detection of damage to DNA and antioxidant activity, first, the CV records with the DNA biosensors of different composition (DNA/GCE, NAF/DNA/GCE, CHIT/DNA/GCE and PVA/DNA/GCE) were obtained as described 
above. Then, after rinsing with water, the biosensors were incubated in the cleavage agent diluted with PB (1 : 1 (v/v) ratio) at an ambient temperature for a given time (2 and $5 \mathrm{~min}$ ) under stirring. After washing the electrode with water, the CV measurements were performed again. The same approach was utilized for the incubation of the biosensor in the mixture of cleavage agent and white wine sample (1: 1 (v/v) ratio).

The portion of survived DNA (surv DNA) after the incubation of the biosensor in the cleavage agent was expressed as the normalized biosensor response calculated according to the equation 1 (Hlavata et al., 2014):

$$
\Delta I=\frac{I_{\text {surv DNA }}-I_{\mathrm{GCE}}}{I_{\mathrm{DNA}}-I_{\mathrm{GCE}}} \times 100
$$

where $I_{\text {surv DNA }}$ and $I_{\mathrm{DNA}}$ are the $\mathrm{CV}$ anodic currents of the $1 \mathrm{mM}\left[\mathrm{Fe}(\mathrm{CN})_{6}\right]^{3-/ 4-}$ redox indicator system measured at the DNA/GCE, NAF/DNA/GCE, CHIT/DNA/GCE and PVA/DNA/GCE biosensors at the peak potential obtained at the bare GCE at which the anodic peak current $I_{\mathrm{GCE}}$ was also evaluated.

The DNA damage experiments were repeated three times, and the CV measurements were repeated also three times for each DNA damage experiment (the coverage intervals were calculated and the error bars were constructed for the significance level $\alpha=0.05$ ).

\section{Results and discussion}

\section{Selection of biosensor protective membranes}

Four types of biosensors, simple DNA/GCE and polymer membrane-covered electrodes, NAF/ DNA/GCE, CHIT/DNA/GCE and PVA/DNA/ GCE, were tested with respect to their response after incubation in white wines. Following 2 and 5 min incubation, the biosensors were rinsed with water, transferred to $1 \mathrm{mM}\left[\mathrm{Fe}(\mathrm{CN})_{6}\right]^{3-/ 4-}$ solution, and the $\mathrm{CV}$ measurements were performed. The relative standard deviation $(R S D)$ of the $\mathrm{CV}$ current data obtained during the repeated measurements $(n=3)$ was about $2.5 \%$.

The $I_{\mathrm{p}}$ response of the redox indicator for DNA/ GCE decreased with time of the biosensor incubation what can be described to the adsorption of high molecular weight substances present in white wines leading to the sensor surface fouling. To eliminate this undesirable behavior, three types of external protective membranes, Nafion (NAF), chitosan (CHIT) and polyvinylalkohol (PVA) were prepared and tested (Fig. 1A). The amount of polymer deposited on the DNA/GCE surface was optimized with respect to biosensor response value. For the biosensors with the negatively charged NAF and neutral PVA films, the $\mathrm{CV}$ response of the negatively charged indicator $\left[\mathrm{Fe}(\mathrm{CN})_{6}\right]^{3-/ 4-}$ is diminished comparing to the simple DNA/GCE biosensor, and for that with the positively charged CHIT film, the response is higher than for DNA/GCE due to the electrostatic preconcentration of the $\left[\mathrm{Fe}(\mathrm{CN})_{6}\right]^{3-/ 4-}$ anion within the positively charged polymer.

For the NAF/DNA/GCE, CHIT/DNA/GCE and PVA/DNA/GCE biosensors, fouling caused by white wines matrix was diminished and the $\mathrm{CV}$ responses of these biosensors exhibited lower dependence on time of the incubation in white wines. Based on the voltammograms depicted in Fig. 1A, the PVA membrane was proved to be the most suitable membrane for the protection of the biosensor from the interferences. On Fig. 2, this improvement of the $\mathrm{CV}$ response stability is shown by a comparison of the indicator anodic peak current obtained at DNA/GCE and PVA/DNA/GCE biosensors after 2 and $5 \mathrm{~min}$ incubation in various wines. Based on these tests, the PVA/DNA/GCE biosensor was used in further tests for the detection of a deep degradation of the surface-attached DNA and for the evaluation of antioxidant properties of white wines.

\section{Detection of the DNA degradation using the biosen- sors with the external PVA membrane}

DNA degradation by hydroxyl radicals generated via cleavage mixture of the $\mathrm{Fe}(\mathrm{II})$ ions and $\mathrm{H}_{2} \mathrm{O}_{2}$ was detected and evaluated using the $\mathrm{CV}$ response of various electrodes modified with the PVA membrane. Fig. 1B represents CVs of $1 \mathrm{mM}$ $\left[\mathrm{Fe}(\mathrm{CN})_{6}\right]^{3-/ 4-}$ in PB obtained before and after the treatment of PVA/GCE, DNA/GCE and PVA/ DNA/GCE in the cleavage agent for 2 and $5 \mathrm{~min}$. Simple PVA/GCE electrode exhibited excellent response stability under given conditions indicating that the PVA film is not destroyed oxidatively by ROS. An increase in $\mathrm{CV}$ peak current of the redox indicator together with a decrease of the anodic to cathodic peak potential separation have been found after incubation of DNA/GCE biosensor in the cleavage mixture. These changes reflect to the DNA layer degradation process at the electrode surface when the original negatively charged DNA backbone is nicked, rests of DNA are leaching from the electrode surface lowering the electrostatic repulsion between the DNA and $\left[\mathrm{Fe}(\mathrm{CN})_{6}\right]^{3-/ 4-}$ indicator. As a result, the voltammograms shape becomes developed similarly to that obtained at the electrode without DNA.

Ability of the PVA membrane to transport ROS through it without affecting the detection of DNA degradation was confirmed using the PVA/DNA/ 

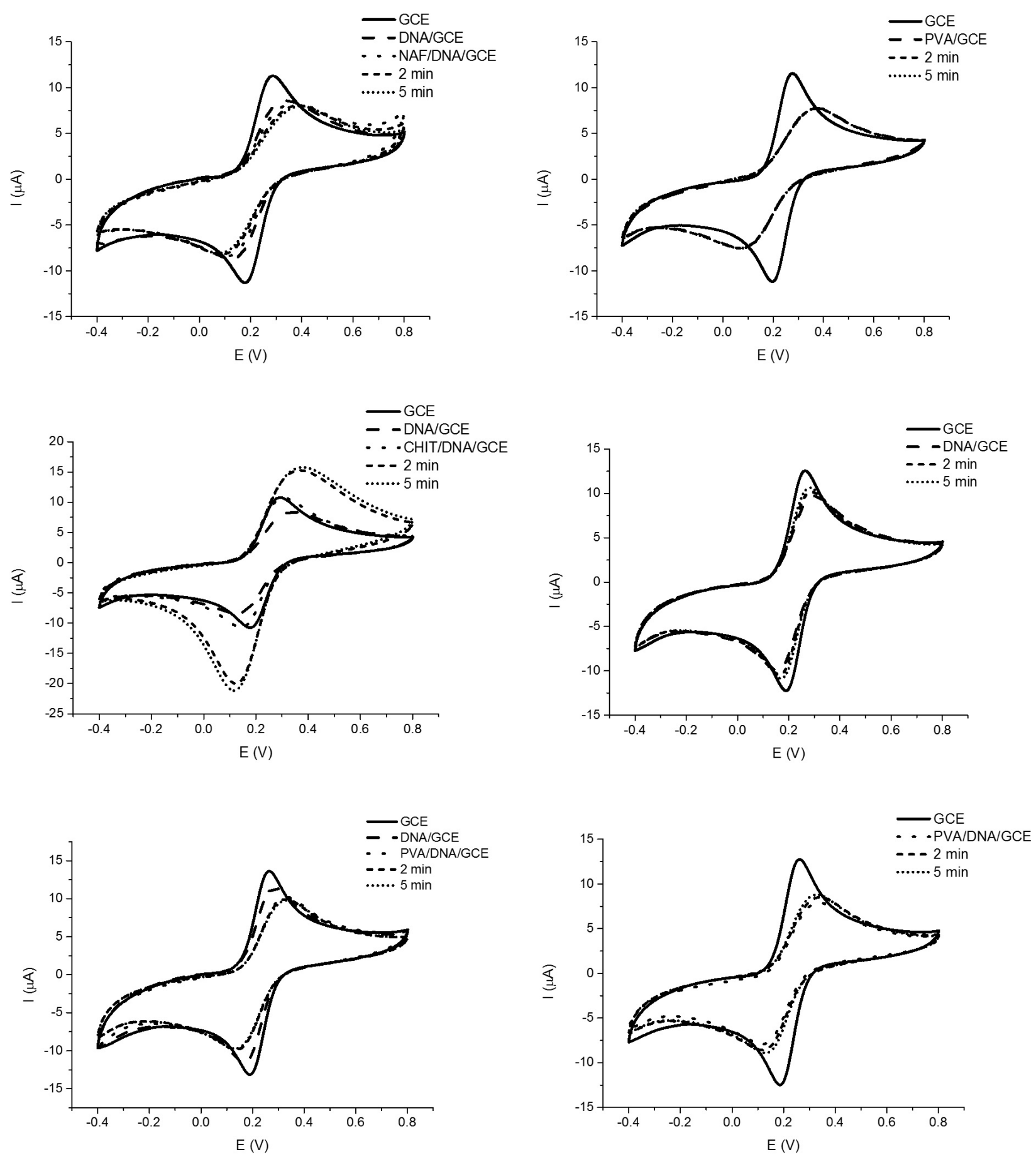

A

B

Fig. 1. (A) Evaluation of various external protective membranes towards a wine fouling effect. CVs of $1 \mathrm{mM}\left[\mathrm{Fe}(\mathrm{CN})_{6}\right]^{3-/ 4-}$ in PB at GCE, DNA/GCE and DNA/GCE electrodes with NAF, CHIT and PVA protective membranes recorded before and after incubation in Green Veltliner

(diluted $1: 1(\mathrm{v} / \mathrm{v})$ with PB) for 2 and $5 \mathrm{~min}$.

(B) Evaluation of the PVA membrane for the detection of DNA degradation. CVs of $1 \mathrm{mM}\left[\mathrm{Fe}(\mathrm{CN})_{6}\right]^{3-/ 4-}$ in $\mathrm{PB}$ recorded before and after incubation of the PVA/GCE, DNA/GCE and PVA/DNA/GCE electrodes in the cleavage agent (diluted $1: 1(\mathrm{v} / \mathrm{v})$ with $\mathrm{PB})$ for 2 and $5 \mathrm{~min}$.

GCE biosensor under the same conditions. The increase in $\mathrm{CV}$ peak current of the redox indicator and decrease of the anodic to cathodic peak potential separation was likely the same as with DNA/GCE.
Evaluation of the antioxidant activity of white wines Effect of antioxidants present in different white wines (Müller Thurgau, Pinot Blanc, Traminer, Green Veltliner, Riesling, Chardonnay) against 


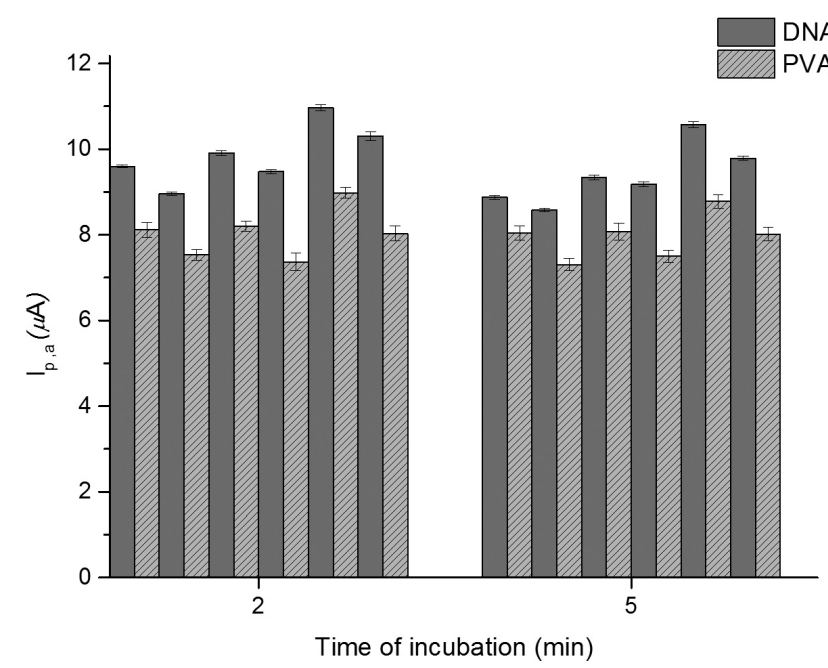

Fig. 2. Evaluation of DNA/GCE and PVA/DNA/GCE response stability to $1 \mathrm{mM}\left[\mathrm{Fe}(\mathrm{CN})_{6}\right]^{3-/ 4-}$ after the incubation of biosensors in white wines (diluted $1: 1(\mathrm{v} / \mathrm{v})$ with $\mathrm{PB}$ ) for given time. From left to right: Müller Thurgau, Pinot Blanc, Traminer, Green Veltliner, Riesling, Chardonnay.



Fig. 3. Evaluation of antioxidant activity of white wines towards hydroxyl radicals as the DNA cleavage agent expressed by the dependence of the normalized PVA/DNA/CGE biosensor response to $1 \mathrm{mM}\left[\mathrm{Fe}(\mathrm{CN})_{6}\right]^{3-/ 4-}$ after the biosensor incubation in the mixture of white wine and the cleavage agent $(1: 1(\mathrm{v} / \mathrm{v}))$ for given time. For comparison,

the response corresponding to the biosensor incubation

in the cleavage agent only (diluted $1: 1(\mathrm{v} / \mathrm{v})$ with

$\mathrm{PB})$ is shown in the first column.

From left to right: Müller Thurgau, Pinot Blanc, Traminer, Green Veltliner, Riesling, Chardonnay.

oxidative damage to DNA has been tested using an incubation of the PVA/DNA/GCE biosensor in the cleavage agent mixed with white wine $(1: 1(\mathrm{v} / \mathrm{v})$ ratio). Changes in the biosensor response were evaluated and compared to those obtained in the presence of cleavage agent only (Fig. 3). As expected, the normalized biosensor response shows significant antioxidant effect of all white wines under investigation towards oxidative damage to the surface confined DNA when about $87 \%$ to $96 \%$ portion of the survived DNA was detected after the biosensor incubation in the mixtures of cleavage agent and white wine comparing to $65 \%$ and $79 \%$ found in the absence of wines. This indicates the ability of white wines to capture the reactive oxygen species during given incubation time. Based on the performed tests, Müller Thurgau was the wine with the highest antioxidant activity.

White wines contain about $9 \%$ of total polyphenols (Saura-Calixto and Diaz-Rubio, 2007). Moreover, antioxidant properties of white wines are influenced by the preparation process, storage conditions, etc. (Lachman et. al., 2009). De Beer et al. determined the antioxidant activity by the DPPH radical with significant differences between individual varieties of white wines. Among the white cultivar wines, the highest antioxidant activity was found for the wines with the highest amount of flavanols, flavonols and hydroxycinnamates (De Beer et al., 2003).

\section{Conclusion}

Fast, simple and cost-effective determining of antioxidant properties of white wines is of high importance. DNA is generally accepted as a biochemical substrate suitable for an evaluation of antioxidant effects toward oxidative damage. Fouling of the DNA/GCE biosensor surface at the incubation in white wines was found. Using the biosensor with external PVA protective membrane, the necessary sensitivity to the detection of immobilized DNA and its deep oxidative degradation by the specific cleavage agent has been achieved and the antioxi- 
dant activity of selected white wines was evaluated. The wines under investigation exhibited similar antioxidant effects which is in accordance with some literature data (Jakubec et al., 2012; Lachman et al., 2009).

The present study demonstrates the efficiency of the external membranes towards biosensor fouling in complex matrices. The approach reported here can be useful for the development of similar simple, inexpensive and effective tools for warning tests of the DNA degradation by risk chemicals in complex matrices as well as for assays of antioxidant activity.

\section{Acknowledgement}

This publication was supported by the Scientific Grant Agency VEGA of the Slovak Republic (Project No 1/0361/14), the Slovak Research and Development Agency under the Contract No. APVV-0797-11, and the Competence Centre for SMART Technologies for Electronics and Informatics Systems and Services (Project ITMS 26240220072) funded by the Research E Development Operational Programme from the ERDF.

\section{References}

Ambrózy A, Hlavatá L, Labuda J (2013) Acta Chim. Slovaca 6: 35-41.

Campanella L, Bonanni A, Finotti E, Tomassetti M (2004) Biosensors and Bioelectronics 19(7): 641-51.

De Beer D, Joubert E, Gelderblom WCA, Manley M (2003) Journal of Agricultural Food Chemistry 51(4): 902-909.

Di Majo D, Guardia ML, Giammanco S, Neve LL, Giammanco M (2008) Food Chemistry 111(1): 45-49.

Ferancová A, Heilerová L, Korgová E, Šilhár S, Štepánek I, Labuda J (2004) Eur. Food Res. Technol. 219: 416-420.

Fojta M (2005) in Electrochemistry of Nucleic Acids and Proteins. Towards Electrochemical Sensors for Genomics and Proteomics (Eds: Palecek E, Scheller F, Wang J) Elsevier, Amsterdam pp 386-431.

Galandova J, Labuda J (2009) Chem. Papers 63: 1, 1-14.

Heilerová L, Bučková M, Tarapčík P, Šilhár S, Labuda J (2003) Czech. J. Food Chem., 21: 78-84.

Hlavatá L, Vyskočil V, Beníková K, Borbélyová M, Labuda J (2014) Central European Journal of Chemistry 12(5): 604-611.
Jakubec P, Bancirova M, Halouzka V, Lojek A, Ciz L, Denev P, Cibicek N, Vacek J, Vostalova J, Ulrichova J, Hrbac J (2012) J. Agric. Food Chem. 60: 7836-7843.

Kilmartin PA, Zou H, Waterhouse AL (2001) Journal of Agricultural and Food Chemistry 49: 1957-1965.

Kim JO, Park JK, Kim JH, Jin SG, Yong CS, Li DX et al. (2008) International Journal of Pharmacology 359: 79-86.

Kirsanov D, Mednova O, Vietoris V, Kilmartin PA, Legin A (2012) Talanta 90:109-16.

Labuda J (2011) in Nucleic Acid Biosensors for Environmental Pollution Monitoring (Eds: Mascini M, Palchetti I) Royal Society of Chemistry, Cambridge pp 121-140.

Labuda J, Bučková M, Heilerová L, Šilhár S, Štepánek S (2003) Anal. and Bioanal. Chem. 376: 168-173.

Labuda J, Vyskocil V (2011) in Encyclopedia of Applied Electrochemistry, DNA/Electrode Interface (Eds: Savinell RF, Ota K, Kreysa G) Springer, Berlin pp 4.

Lachman J, Šulc M, Faitová K, Pivec V (2009) in International Journal of Wine Research 1 pp 101-121.

Leceta I, Guerrero P, de la Caba K (2013) Carbohydrate Polymers. 93: 339-346.

Mannino S, Brenna O, Buratti S, Cosio MS (1998) Electroanalysis 10: 908-912.

Mello LD, Kubota LT (2007) Talanta 72: 335-348.

Mulyasuryani A, Roosdiana A, Srihardyastutie A (2010) Indonesian Journal of Chemistry 10: 162-166.

Poyrda S, Jaffrezic-Renault N, Martelet C, Cosnier S, Labble P (1998) Analytica Chimica Acta 364: $165-169$.

Saura-Calixto F, Diaz-Rubio ME (2007) Food Research International 40(5): 613-619.

Srinivasa PC, Ramesh MN, Kumar KR, Tharanathan RN (2003) Carbohydrate Polymers 53: 431-438.

Tripathi S, Mehrotra GK, Dutta PK (2010) Carbohydrate Polymers 79: 711-716.

Vyskocil V, Labuda J, Barek J (2010) Anal. Bioanal. Chem. 397: 233.

Zajoncová L, Pospíšková K (2009) Chem. Listy 103: 291-301.

Ziyatdinova G, Galandová J, Labuda J (2008) Internatl. J. Electrochem. Sci. 3: 223-235.

Ziyatdinova G, Labuda J (2012) Electroanalysis 24: 12, 2333-2340.

Yang L, Wang GC, Liu YJ, An JJ, Wang M (2013) Analytical and Bioanalytical Chemistry 8: 25452552. 